\title{
Genetic diversity among accessions of acerola based on the quality of fruits
}

\author{
Deniete Soares Magalhães, José Carlos Moraes Rufini, Alejandra Semiramis Alburquerque, \\ Renata Elisa Viol, Miriã Cristina Pereira Fagundes*, Thatiane Padilha de Menezes
}

\begin{abstract}
Knowledge of the quality of fruits and the genetic variability among genotypes of acerola is important to optimize the use of genetic resources in improvement programs. The objective of the present study was to assess physico-chemical characteristics to determine genetic divergence among 24 genotypes of acerola. Sixty ripe fruits were collected per plant in a commercial orchard in the municipality of Jequitibá-MG. They were assessed in two production seasons with regard to their physical, chemical, and physico-chemical characteristics. Multivariate analysis of the genetic divergence among the genotypes was performed using principal component analysis, Tocher's clustering method, and the nearest-neighbor hierarchical method, using the standardized mean Euclidean distance as the measure of dissimilarity. Genotypes 13, 20, and 23 exhibited means that were higher than the overall mean values for the main characteristics (fruit mass, ratio, and vitamin C content). Genotypes 3, 6, 8, 21, and 24 stood out with regard to fruit mass and ratio, i.e., they were larger and sweeter. Genotype 16 stood out with regard to fruit mass and vitamin $C$ content. Results obtained using the methods were comparable, and the methods were effective in discriminating between the genotypes. This indicated variability, with potential for use in improvement programs. Based on the mean values for the chemical and physical characteristics of fruits and considering the genetic divergence among the genotypes, it was possible to suggested nine crosses to generate a future improved population, namely between genotype 11 and genotypes $3,6,8,13,16,20,21,23$, and 24.
\end{abstract}

Keywords: ascorbic acid, Malpighia emarginata D. C., genetic improvement

\section{Introduction}

Brazil has ideal conditions for the cultivation of acerola and is one of the world's largest producers of this fruit, which is notable for its high vitamin $C$ content and for being a source of carotenoids, provitamin A, thiamin, riboflavin, niacin, and minerals such as calcium, iron, and phosphorous. Acerola may be consumed fresh or used in the processing of several food products, especially in the pharmaceutical industry, and as a food supplement (Segtowick et al., 2013; Reis et al., 2017). There has been a recent increase in the demand for acerola in domestic and international markets, especially due to the promotion of functional food consumption, which has boosted the planting of new orchards (Ferreira et al 2009, Ritzinger \& Ritzinger, 2011).

As a result of this expansion, the genetic variability that exists in commercial orchards of acerola, which is mostly the result of seed propagation, is associated with some disadvantages such as the segregation of plant and fruit characteristics, resulting in highly heterogeneous orchards in terms of quality and quantity. This hinders farming practices, in particular the farms' harvesting systems (Moura et al., 2007; Oliveira et al., 2009). The lack of established commercial varieties that ensure high fruit quality and yield reflects the need to genetically improve the crop. 
Commercial production requires that producers be provided with adapted genetic materials with superior characteristics that favor production. Studies on fruit and seed morphology and chemical characterization of fruit pulp are used to aid programs of pre-improvement of non-domesticated species (Moura et al., 2013) and to determine the genetic variability among individuals or accessions of a population (Almeida Júnior et al., 2014).

Therefore, together with the analysis of the performance of the accessions, studies on genetic divergence are of great importance for improvement programs because they assess variability among accessions (Silva et al., 2017) and provide information for the identification of mother plants that can be used in crosses with a higher probability of obtaining superior progeny in the segregating generations. Genetic diversity may be studied using various methods such as the use of molecular markers (Almeida et al., 2011 ), the coefficient of parentage (Costa e Silva et al., 2014), and multivariate analysis (Assis et al., 2014).

Genetic divergence has been assessed through predictive biometric techniques that consider the morphological and physiological differences between parent materials (Cruz et al., 2012). The predictive techniques available include principal component analysis, Tocher's clustering method, and the nearest-neighbor hierarchical method.

The objective of this study was to assess the genetic divergence among different accessions of acerola by qualitative analyses of fruits to identify superior materials that can be used in future improvement programs.

\section{Material and methods}

The experimental material was obtained from a 15-year-old commercial acerola orchard, in the municipality of Jequitibá-MG, located at latitude $19^{\circ} 15^{\prime} \mathrm{S}$ and longitude $44^{\circ} 15^{\prime} \mathrm{W}$ and at an altitude of $644 \mathrm{~m}$. The mean annual temperature is $20.2^{\circ} \mathrm{C}$, the mean annual rainfall is $1328.7 \mathrm{~mm}$, and the climate is humid tropical (IGA, 2012). The orchard had approximately 800 plants of acerola and exhibited phenotypic variability, the result of sexual propagation of materials collected from various localities. The area does not have an irrigation system and all plants in the orchard were under the same soil conditions and under the cultivation practices recommended for this crop. Among these plants, 24 were pre-selected for the study based on their history, vigor, yield, and health. For each accession, 60 fruits per plant were randomly collected at the physiological maturation stage, which was determined by their intense red color, in two production seasons. After harvesting, the fruits were adequately packaged, labeled, and sent to the Laboratory of Plant Production at the Sete Lagoas campus of the Federal University of São João Del Rei, to be assessed.

The following characteristics were evaluated in each of the two production seasons, according to the methodologies proposed by the Adolfo Lutz Institute (IAL, 2008): mean fruit mass in $g$ (FM), mean seed mass in $g$ (SM), and mean pulp mass in $\mathrm{g}$ (PM) (all measured with digital precision scales); pulp yield in \% (PY); volume in $\mathrm{mL}(\mathrm{VO})$, obtained by immersing the fruits in a graduated cylinder with water; longitudinal diameter of the fruit in $\mathrm{mm}$ (LD) and transverse diameter of the fruit in $\mathrm{mm}$ (TD) (both measured with a digital pachymeter); shape index (SI) (the ratio between the longitudinal diameter and the transverse diameter); hydrogen ionic potential $(\mathrm{pH})$; titratable acidity in \% of malic acid (TA), determined by titration; total soluble solids in Brix (TSS), obtained by refractometry; ratio (the ratio between soluble solids and titratable acidity); fruit pulp moisture in \% (PM), calculated based on the fresh and dry masses of the fruit pulp, which were determined before and after drying in a vacuum oven at $70^{\circ} \mathrm{C}$ until constant weight.

The method described by Benlloch et al. (1993), using a SHIMADZU high-performance liquid chromatographer (CLAE) with a UV-visible detector, was used to determine the ascorbic acid content (vitamin C) and the results were expressed in $\mathrm{mg}$ of ascorbic acid per $100 \mathrm{~g}$ of fresh pulp.

The mean of the values obtained in the two production seasons for each characteristic of the different accessions of acerola assessed were subjected to descriptive analysis and the results were expressed as mean, standard deviation, 
and coefficient of variation. Genetic divergence among the accessions was studied using principal component analysis, the nearest-neighbor hierarchical method, and Tocher's optimization method. The standardized mean Euclidean distance was used as a measure of dissimilarity. The cophenetic correlation coefficient ( $r$ ) was used to calculate the dendrogram and Pearson's correlation. All analyses were performed using the GENES software (Cruz, 2013).

\section{Results and discussion}

Variability was observed among the 24 accessions based on the quality of the fruits (Table 1). This variability may be exploited to select better individuals to be used as clonal varieties or as the basis for the selection of parents to be used in crosses.

The means of fruit mass of the accessions varied between 2.63 and $6.51 \mathrm{~g}$ (Table 1). In $79.17 \%$ of the evaluated accessions, the mean fruit mass was greater than $4 \mathrm{~g}$. Moura et al. (2007) evaluated 45 clones of acerola and reported a mass variation between 3.33 and $11.75 \mathrm{~g}$, whereas Santos et al. (2012) assessed fruits from various localities and obtained a range between 5.45 and $7.21 \mathrm{~g}$. Lima et al. (2014) reported a range between 4.03 and $7.10 \mathrm{~g}$ among six accessions of acerola in the region of Muzambinho-MG. These variations are probably due to the different edaphoclimatic conditions of the crop environments and the intrinsic genetic differences between the analyzed materials.

The mean seed mass ranged between 0.53 and $1.59 \mathrm{~g}$ and the mean pulp mass varied between 2.10 and $5.18 \mathrm{~g}$. These results differed from those obtained by Carpentieri-Pípolo et al. (2000). They analyzed 14 genotypes of acerola and the seed and pulp means ranged between 0.61 and $2.90 \mathrm{~g}$ and between 2.28 and $7.28 \mathrm{~g}$, respectively. The mean fruit volume of the accessions was between 2.00 and $5.68 \mathrm{~mL}$. According to Gonzaga et al. (1999), the larger the fruits, the easier and quicker the harvest because there is less labor involved and, consequently, reduced production costs, and the fruits are more attractive for consumption.

Pulp yield ranged between $67.17 \%$ and $81.76 \%$, which is a satisfactory result for the pulp processing industry. These values are within the range reported by Carpentieri-Pípolo et al. (2000), who obtained means between 61.36 and $87.78 \%$. Maciel et al. (2010) assessed 18 genotypes of acerola and reported yield means between $41.06 \%$ and $72.54 \%$. According to these authors, this is an essential quality characteristic of acerola destined for processing because it directly affects the cost/benefit ratio.

The longitudinal diameter of the fruits varied between 16.56 and $22.42 \mathrm{~mm}$ and the transverse diameter ranged between 17.59 and $25.48 \mathrm{~mm}$. These values are greater than those obtained by Lima et al. (2014), who reported a mean longitudinal diameter between 15.39 and $20.05 \mathrm{~mm}$ and a transverse diameter between 16.67 and $23.86 \mathrm{~mm}$. However, these variations were similar to those indicated by Santos et al. (2012), who obtained longitudinal and transverse diameters varying between 17.91 and $21.48 \mathrm{~mm}$ and between 22.33 and $24.04 \mathrm{~mm}$, respectively.

The shape index, which is expressed by the ratio between the longitudinal and transverse diameters, ranged between 0.80 and 0.95, a result that confirms that acerola has a subglobular shape. The closer the shape index is to 1.0, the more the fruits tend to have a round shape. The values obtained are in line with those reported by Lima et al. (2014). Fruit diameter and shape index are important attributes for the markets because they affect the attractiveness of the fruit and, therefore, the consumer's choice of individual fruits.

The mean $\mathrm{pH}$ ranged between 2.97 and 3.75. This result is similar to those obtained by Mariano-Nasser et al. (2017) (2.85 - 3.39), Batista et al. (2015) (3.15 - 3.30), and Santos et al. (2012) (3.3 - 3.52). This parameter is a factor of great influence on the quality and safety of food products and its assessment is very important in the industrial processing of fruit pulp because it gives an indication of its conservation potential, which is demonstrated by the developed acidity. With regard to soluble solids, the mean values were between 5.56 and $8.55^{\circ}$ Brix. These values are higher those obtained by Santos et al. (2012), who reported means between 4.7 and $5.3^{\circ}$ Brix. The variations presented in that study are within the range for soluble solids described 
Table 1. Univariate analysis of the quality of acerola fruits: Mean (M), minimum value (Min), maximum value (Max), coefficient of variation (CV), and standard deviation (SD) of the characteristics of the fruits of the acerola accessions in two production seasons

\begin{tabular}{|c|c|c|c|c|c|c|c|c|c|c|c|c|c|c|}
\hline Access & FM & $S M$ & PM & PY & VO & LD & TD & SI & $\mathrm{pH}$ & TSS & TA & Ratio & $P M$ & Vit.C \\
\hline 1 & 2.99 & 0.55 & 2.44 & 81.41 & 2.42 & 17.21 & 19.03 & 0.90 & 3.54 & 6.95 & 1.58 & 4.64 & 90.04 & $1,184.90$ \\
\hline 2 & 4.52 & 0.94 & 3.58 & 79.18 & 3.88 & 19.25 & 21.23 & 0.90 & 3.37 & 5.56 & 1.00 & 5.90 & 90.77 & 902.29 \\
\hline 3 & 4.87 & 1.12 & 3.76 & 76.94 & 4.49 & 19.71 & 22.45 & 0.88 & 3.33 & 6.16 & 0.91 & 6.90 & 92.27 & $1,051.29$ \\
\hline 4 & 4.12 & 0.92 & 3.19 & 77.43 & 3.32 & 19.70 & 20.82 & 0.95 & 3.31 & 7.70 & 1.07 & 7.59 & 90.51 & $1,039.10$ \\
\hline 5 & 4.10 & 1.14 & 2.96 & 72.10 & 3.31 & 21.35 & 19.10 & 0.91 & 3.48 & 7.13 & 1.05 & 6.89 & 91.05 & 874.24 \\
\hline 6 & 6.17 & 1.33 & 4.84 & 78.00 & 5.25 & 21.17 & 24.76 & 0.85 & 3.62 & 6.31 & 1.04 & 6.14 & 91.46 & 900.41 \\
\hline 7 & 4.52 & 1.18 & 3.34 & 74.09 & 3.83 & 19.35 & 21.56 & 0.90 & .26 & 7.53 & 1.87 & 4.88 & 91.89 & $1,043.10$ \\
\hline 8 & 4.97 & 0.92 & 3.29 & 81.76 & 5.58 & 19.70 & 23.25 & 0.86 & 3.71 & 5.65 & 0.86 & 6.63 & 92.33 & 826.62 \\
\hline 9 & 5.64 & 1.12 & 4.52 & 80.40 & 5.05 & 20.62 & 23.99 & 0.86 & 3.27 & 7.26 & 1.62 & 4.65 & 91.19 & $1,084.30$ \\
\hline 10 & 3.62 & 0.84 & 2.79 & 76.88 & 3.50 & 17.40 & 20.87 & 0.83 & 2.97 & 6.71 & 1.35 & 5.01 & 91.95 & $1,359.95$ \\
\hline 11 & 2.63 & 0.53 & 2.10 & 77.97 & 2.00 & 16.56 & 17.59 & 0.94 & 3.04 & 8.55 & 3.13 & 3.01 & 90.29 & $1,721.80$ \\
\hline 12 & 3.99 & 0.89 & 3.09 & 76.76 & 3.22 & 18.20 & 20.38 & 0.90 & 3.41 & 6.66 & 1.72 & 4.07 & 90.77 & $1,381.20$ \\
\hline 13 & 5.29 & 1.22 & 4.07 & 76.63 & 4.42 & 19.93 & 22.95 & 0.87 & 3.75 & 6.24 & 1.06 & 5.92 & 90.11 & $1,311.90$ \\
\hline 14 & 4.30 & 0.86 & 3.44 & 79.95 & 3.58 & 19.29 & 21.62 & 0.89 & 3.68 & 5.75 & 1.29 & 5.06 & 91.25 & $1,227.80$ \\
\hline 15 & 4.42 & 0.93 & 3.49 & 78.78 & 3.70 & 17.98 & 22.07 & 0.82 & 3.30 & 7.15 & 1.52 & 4.72 & 90.55 & $1,432.60$ \\
\hline 16 & 5.26 & 1.28 & 3.98 & 74.47 & 4.08 & 19.98 & 22.85 & 0.88 & 3.31 & 8.03 & 1.83 & 4.97 & 91.36 & $1,231.70$ \\
\hline 17 & 4.11 & 0.87 & 3.24 & 78.80 & 3.84 & 20.05 & 21.08 & 0.95 & 3.26 & 6.03 & 1.15 & 5.33 & 92.36 & $1,126.80$ \\
\hline 18 & 5.92 & 1.45 & 4.47 & 75.28 & 5.04 & 22.42 & 24.12 & 0.93 & 3.51 & 6.5 & 1.58 & 4.49 & 90.95 & $1,128.50$ \\
\hline 19 & 3.50 & 1.12 & 2.37 & 67.17 & 2.81 & 17.92 & 19.57 & 0.92 & 3.32 & 8.14 & 1.68 & 5.19 & 90.11 & $1,364.47$ \\
\hline 20 & 4.69 & 0.95 & 3.74 & 79.66 & 3.46 & 19.98 & 21.83 & 0.92 & 3.43 & 6.18 & 0.98 & 6.67 & 91.57 & $1,266.70$ \\
\hline 21 & 6.20 & 1.59 & 4.62 & 74.38 & 4.21 & 20.03 & 25.24 & 0.80 & 3.04 & 6.29 & 1.69 & 4.21 & 91.13 & $1,323.90$ \\
\hline 22 & 4.03 & 0.98 & 3.06 & 75.70 & 4.00 & 18.98 & 20.91 & 0.91 & 3.38 & 8.46 & 2.20 & 5.93 & 90.33 & $1,178.40$ \\
\hline 23 & 4.77 & 1.04 & 3.73 & 78.22 & 4.08 & 19.15 & 22.50 & 0.85 & 3.57 & 7.08 & 0.93 & 8.31 & 92.24 & $1,823.40$ \\
\hline 24 & 6.51 & 1.33 & 5.18 & 79.77 & 5.68 & 21.93 & 25.48 & 0.86 & 3.35 & 6.99 & 1.19 & 5.90 & 92.32 & 994.36 \\
\hline$M$ & 4.63 & 1.05 & 3.55 & 77.16 & 3.95 & 19.50 & 21.14 & 0.89 & 3.38 & 6.88 & 1.43 & 5.46 & 91.20 & $1,202.81$ \\
\hline Min & 2.63 & 0.53 & 2.10 & 67.17 & 2.00 & 16.56 & 17.59 & 0.80 & 2.97 & 5.56 & 0.86 & 3.01 & 90.04 & 826.62 \\
\hline Max & 6.51 & 1.59 & 5.18 & 81.76 & 5.68 & 22.42 & 25.48 & 0.95 & 3.75 & 8.55 & 3.13 & 8.31 & 92.36 & $1,823.40$ \\
\hline $\mathrm{CV}$ & 21.50 & 24.80 & 22.00 & 4.72 & 23.50 & 7.48 & 9.02 & 9.37 & 6.00 & 12.60 & 26.10 & 23.02 & 0.96 & 20.12 \\
\hline SD & 0.99 & 0.26 & 0.78 & 3.62 & 0.93 & 1.45 & 1.98 & 0.08 & 0.20 & 0.86 & 0.51 & 1.26 & 0.78 & 242.52 \\
\hline
\end{tabular}

by Moura et al. (2007), who obtained values between 3.33 and $11.75^{\circ}$ Brix.

Titratable acidity varied between $0.86 \%$ and $2.20 \%$. This result differed from that reported by Santos et al. (2012) (0.86\% - 0.99\%), but was similar to that obtained by Musser et al. (2004) $(0.85 \%$ - 2.04\%). According to Godoy et al. (2008), the acid varieties are preferentially used in the food industry and have an unpalatable flavor due to their high acidity (more than $1 \%$ malic acid). On the other hand, the semi-sweet varieties have intermediate total soluble solid content and total titratable acidity values, which make them acceptable both for processing and consumption.

The ratio means varied between 3.01 and 8.31 , with a mean of 5.46 . These results are in line with those obtained by Santos et al. (2012). The ratio between soluble solids and titratable acidity indicates the degree of balance between the fruit's sugar and organic acid content and is directly related to fruit flavor (Chitarra \& Chitarra, 2005). Therefore, it is an important variable in the selection of table varieties, because the higher the ratio, the sweeter the fruits.

The mean moisture content of the fruits varied between $90.04 \%$ and $92.36 \%$. According to Souza et al. (2008), this factor has great influence on the shelf life of food products because high moisture levels may lead to microbial growth and deterioration in the short term.

$$
\text { Vitamin C content varied }
$$
between $802.62 \mathrm{mg}$ and 1,823.44 $\mathrm{mg}$ per $100 \mathrm{~g}$ of fresh pulp. Moura et al. (2007) analyzed 45 clones of acerola and obtained values between 500.90 $\mathrm{mg}$ and 1,854.92 $\mathrm{mg}$ per $100 \mathrm{~g}$ of fresh pulp. These results refer to ripe fruits. Because vitamin C content is of interest to the pharmaceutical 
industry, it is advantageous to harvest the fruits before ripening as, according to Ferreira et al., 2009, the ascorbic acid content in acerola fruit decreases as ripening progresses.

Accessions 13,20, and 23 stood out with regard to fruit mass, the primary component of the production yield characteristic; ratio, which affects the palatability of fruits; and vitamin C content, an important attribute for nutrition and for the acceptance of acerola in the external markets. The means of these three characteristics in these accessions were higher than the overall mean values. Accessions 3, 6, 8, and 24 stood out with regard to fruit mass and ratio and accessions 16 and 21 were superior with regard to fruit mass and vitamin C content (Table 1). These accessions have potential for use as clonal varieties and also in future crosses because they were superior in at least two of the most important agronomic characteristics or stood out in at least one of them (Oliveira et al., 2009). Moreover, the pulp yield of these nine accessions was greater than $74 \%$, which is the determinant for industrial yield.

The Pearson's coefficients of correlation were significant for several pairs of characteristics involving fruit mass, seed mass, pulp mass, volume, longitudinal diameter, and total soluble solids (Table 2).

The estimates of the correlation between the variables ranged between -0.4057 for $\mathrm{pH} x$ TSS and 0.9836 for FM $\times$ TD.

The highest correlations (higher than 0.90) were obtained between FM and PM (0.9778), between FM and TD (0.9836), between PM and TD (0.9531), and between VO and TD (0.9015). Similar results were obtained by Matias et al. (2014) who studied the correlations between the characteristics of peach fruits and reported that the highest correlations occurred between the physical variables. These correlations are important and may facilitate the analysis of acerola plant selection.

Titratable acidity had a high negative correlation with ratio $(-0.8309)$, i.e., the higher the titratable acidity the lower the ratio. Vitamin C, a desirable trait in acerola fruits, correlated negatively with longitudinal diameter $(-0.5687)$, i.e., the higher the fruit size the lower the vitamin C content.

With regard to genetic divergence, Tocher's optimization method clustered the accessions into five groups (Table 3). Group I encompassed the greatest number of similar accessions (20), accounting for $83.33 \%$ of the total, which suggests that the possible crosses between these offer a lower likelihood of obtaining superior accessions in the segregating generations, because crosses among the same group should be avoided. The remaining groups were each composed of a single accession. Cruz et al. (2012) suggests performing crosses between parent accessions with the greatest possible divergence and good performance to increase heterosis and the chances of generating superior individuals.

Table 2. Pearson's correlations between the characteristics of the fruits of the acerola accessions in two production seasons

\begin{tabular}{|c|c|c|c|c|c|c|c|c|c|c|c|c|}
\hline Variáveis & FM & SM & PM & PY & VO & LD & TD & $\mathrm{pH}$ & TSS & TA & Ratio & PM \\
\hline SM & $0.8564^{* *}$ & & & & & & & & & & & \\
\hline PM & $0.9778^{* *}$ & $0.7848^{* *}$ & & & & & & & & & & \\
\hline VO & $0.8815^{* *}$ & $0.6553^{* *}$ & $0.8328^{* *}$ & 0.2534 & & & & & & & & \\
\hline LD & $0.8197^{* *}$ & $0.752^{* *}$ & $0.7901^{* *}$ & -0.0164 & $0.7532^{* *}$ & & & & & & & \\
\hline $\mathrm{pH}$ & 0.2199 & 0.0552 & 0.1911 & 0.2497 & 0.3311 & 0.3356 & 0.2155 & 0.0591 & & & & \\
\hline TSS & -0.3648 & -0.1216 & -0.364 & $-0.4582 *$ & $-0.4101 *$ & -0.3171 & $-0.4132 *$ & $0.2524-0.4057^{*}$ & & & & \\
\hline TA & -0.3903 & -0.2302 & -0.3731 & -0.2408 & $-0.4656^{*}$ & $-0.466^{*}$ & $-0.4518^{*}$ & $0.2033-0.5094^{*}$ & * $0.7093^{* *}$ & & & \\
\hline Ratio & 0.2216 & 0.1321 & 0.1979 & 0.1093 & 0.2833 & 0.3602 & 0.2553 & $-0.02660 .4318^{*}$ & -0.3261 & $-0.8309 * *$ & & \\
\hline
\end{tabular}


Table 3. Groups formed using Tocher's optimization method, based on the standardized mean Euclidean distance of the acerola accessions

\begin{tabular}{cc}
\hline Group & Accessions \\
\hline I & $7,16,22,15,12,10,17,20,14,3,5,4,9,13,18,6,8,23,21,24$ \\
II & 19 \\
II & 1 \\
V & 2 \\
\hline
\end{tabular}

The dendrogram obtained by the nearest-neighbor method (Figure 1), shows the formation of three main groups, with the cut-off point at $80 \%$ of the total distance. The first and second groups isolated accessions 11 and 2, respectively. The third group was composed of the remaining accessions. The cophenetic correlation coefficient was 0.7101 , i.e., greater than 0.7, the value that indicates an adequate fit of the clustering method. These results are in line with those obtained with Tocher's method since they confirm the high divergence between accessions 19, 1, 2, and 11 and the other accessions.

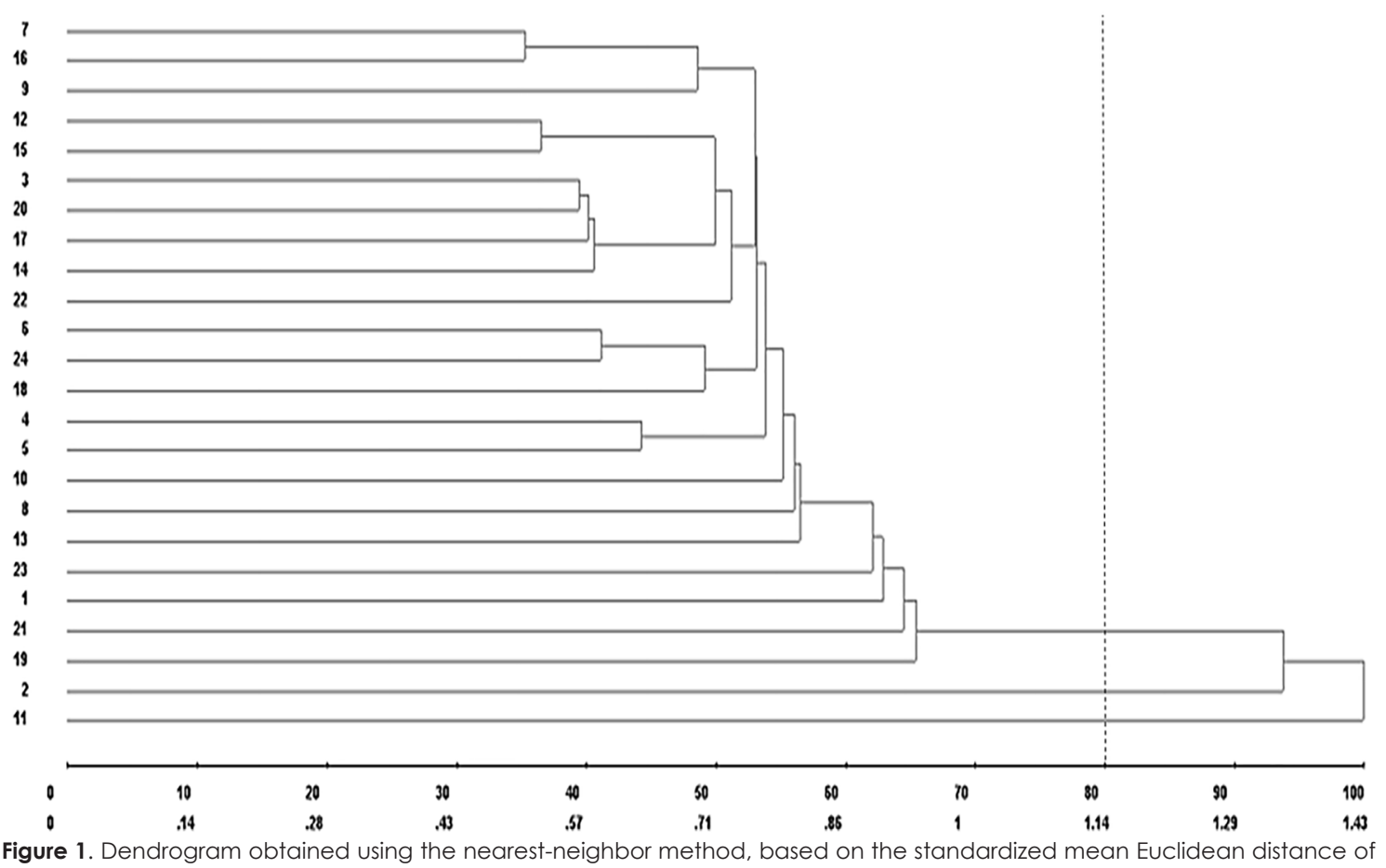

Figure 1. Dendrogram obtained using the nearest-neighbor method, based on the standardized mean Euclidean distance of the acerola accessions.

Several clustering methods, such as Tocher's, Ward's, nearest-neighbor, and UPGMA methods, as well as physical and chemical characteristics, have been widely used in studies on the genetic diversity of fruit species, (Reis et al., 2017; Matias et al., 2016; Silva et al., 2014; Pereira da Silva et al., 2012; Rufini et al., 2011).

In general, researchers have opted for graphical representation when $80 \%$ of the total variation of the data is explained by up to the first four principal components (Cruz et al., 2012). For better visualization, the first three principal components were used for graphical representation, which were sufficient to explain more than $74 \%$ of the observed variation (Table $4)$. The first principal component explained $45.76 \%$ of the variation, with the variable fruit mass having the highest weightage. The second component (seed mass) explained $15.61 \%$ of the variation and the last component (pulp mass) explained $12.90 \%$ of the variation. Accessions close together in the factorial plane are less divergent than accessions that are far apart (Figure 2). The distribution of the accessions allowed confirmation of the individualization of the accessions obtained with Tocher's and nearest-neighbor methods. 
Table 4. Estimation of eigenvalues and the proportion of variance explained by the principal components obtained from the analysis of assessed acerola accession traits

\begin{tabular}{ccc}
\hline Components & \% Variance & \% Accumulated \\
\hline Fruit mass & 45.76 & 45.76 \\
Seed mass & 15.61 & 61.37 \\
Pulp mass & 12.90 & 74.28 \\
Pulp yield & 7.31 & 81.59 \\
Volume & 6.41 & 87.99 \\
Longitudinal diameter & 4.66 & 92.65 \\
Transverse diameter & 2.97 & 95.62 \\
Shape index & 2.23 & 97.84 \\
pH & 1.32 & 99.17 \\
Titratable acidity & 0.50 & 99.66 \\
Total soluble solids & 0.21 & 99.87 \\
Ratio & 0.08 & 99.95 \\
Pulp moisture & 0.03 & 99.98 \\
Vitamin C & 0.02 & 100.00 \\
\hline
\end{tabular}

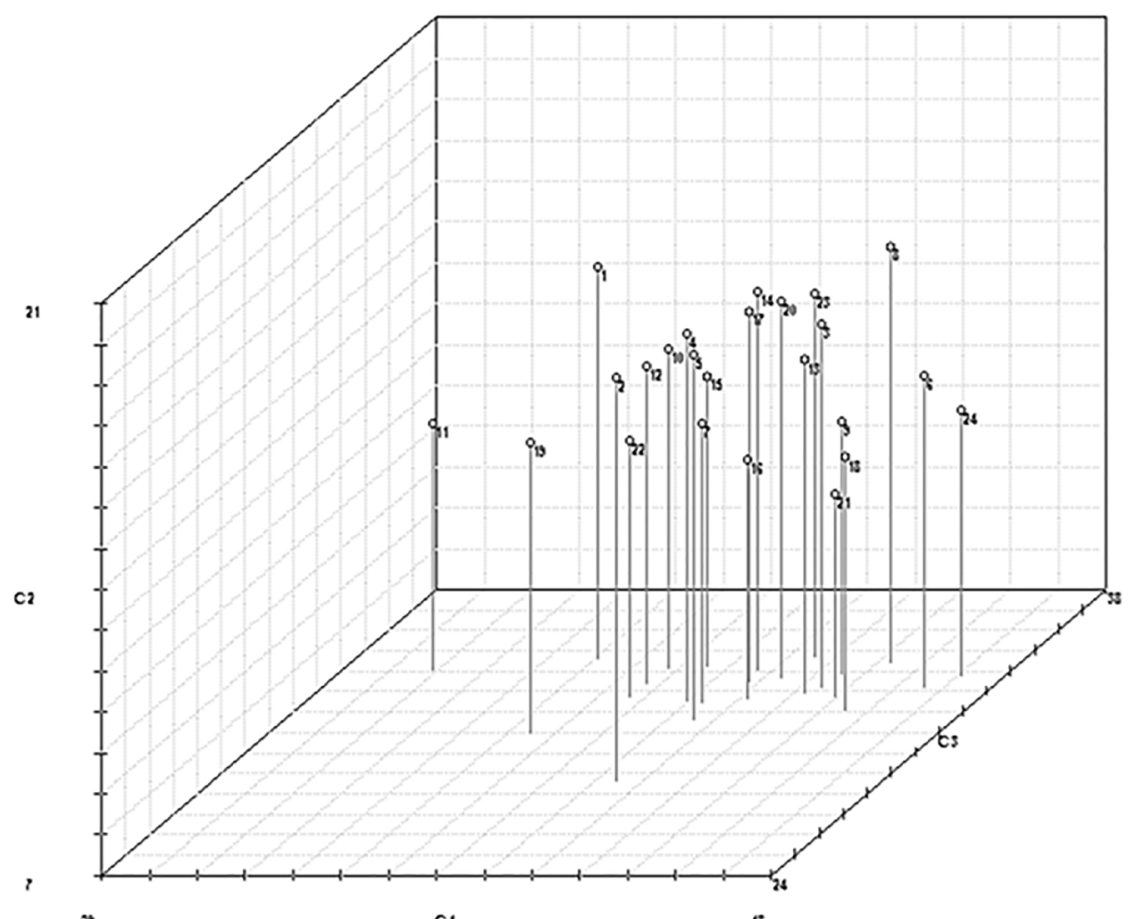

Figure 2 . Distribution of the 14 acerola accessions evaluated with regard to the first three principal components.

Crosses should be indicated based on the means of the accessions' characteristics and the divergence among the accessions. Thus, accessions 1, 2, 11, and 19 were consistently divergent from the remaining accessions by Tocher's (Table 2) and nearest-neighbor methods (Figure 1), both based on the standardized mean Euclidean distance and by the principal component method (Figure 2). Accessions 1, 2, and 19 should not be used in future crosses because they do not have relevant agronomic characteristics (Table 1). Accession 11 stood out for its vitamin C content $(1,721.80 \mathrm{mg}$ per $100 \mathrm{~g}$ of pulp), which was considerably higher than the reference value for the acceptance of acerola for pulp production (a minimum of $800 \mathrm{mg}$ of ascorbic acid per $100 \mathrm{~g}$ of pulp according to the Brazilian legislation). For this reason, this accession could be used in the crop's genetic improvement program.

Thus, to obtain an improved population with good agronomic mean values and that capitalizes the favorable effects of genetic complementation, it is recommended that crosses be made between accession 11 and accessions 3, 6, 8, 13, 16, 20, and 23. 


\section{Conclusions}

There is diversity among the acerola accessions with regard to the quality characteristics of the fruits.

Accessions 13, 20, and 23 have potential for in improvement programs aiming for productivity, based on the characteristics pulp mass, chemical quality, and the ratio between total soluble solids and total titratable acidity.

Accession 11 stood out with regard to vitamin C content and because it diverges genetically from the remaining accessions.

The formation of an improved population with good agronomic mean values and that capitalizes the favorable effects of genetic complementation should involve crosses between accession 11 and accessions 3, 6, 8, 13, $16,20,21,23$, and 24.

\section{Acknowledgements}

We thank CAPES, FAPEMIG, CNPq, and MEC for funding this study.

\section{References}

Almeida, M.C.C., Chiari, L., Jank, L., Valle, C.B. 2011. Diversidade genética molecular entre cultivares e híbridos de Brachiaria spp. e Panicum maximum. Ciência Rural 11: 1998-2003.

Almeida Júnior, E.B., Chaves, L.J., Soares, T.N. 2014. Genetic characterization of a germplasm collection of cagaiteira, a native species of the cerrado. Bragantia 73: 246-252.

Assis, G.M.L., Santos, C.F., Flores, O.S., Valle, C.B. 2014. Genetic divergence among Brachiara humidicola (Rendle) Schweick hybrids evaluated in the Western Brazilian Amazon. Crop Breeding and Applied Biotechnology 14: 224-231.

Batista, P.F., Lima, M.A.C.D., Trindade, D.C.G.D., Alves, R.E. 2015. Quality of different tropical fruit cultivars produced in the Lower Basin of the São Francisco Valley. Revista Ciência Agronômica 46: 176-184.

Benlloch, R., Fane, R., Frigola, A.A. 1993. Quantitative estimate of ascorbic and isoascorbic acid by high performance liquid chromatography application to citric juices. Journal of Liquid Chromatography 16: 3113-3122.

Brasil. Instrução Normativa No 01, DE 7 de janeiro de 2000.Regulamento técnico geral para fixação dos padrões de identidade e qualidade para polpa de fruta. Diário Oficial da República Federativa do Brasil, Brasília, DF, 2000.
Carpentieri-Pípolo, V., Destro, D., Prete, C. E. C., Gonzales, M. G. N., Popper, I., Zanatta, S., SILVA, A. 2000. Seleção de genótipos parentais de acerola com base na divergência genética multivariada. Pesquisa Agropecuária Brasileira, 35:1613-1619.

Chitarra, M. I. F., Chitarra, A. B. 2005. Pós-colheita de frutos e hortaliças: fisiologia e manuseio. UFLA, Lavras, Brasil. 783p.

Costa e Silva, J.O., Cremasco, J.P.G., Matias, R.G.P., Silva, D.F.B., Salazar, A.H., Bruckner, C.H. 2014. Divergência genética entre populações de pessegueiro baseada em características da planta e do fruto. Ciência Rural 10: 1770-1775.

Cruz, C.D., Regazzi, A.J., Carneiro, P.C.S. 2012. Modelos Biométricos Aplicados ao Melhoramento Genético. Editora UFV, Viçosa, Brasil, 516p.

Cruz, C.D. 2013. GENES - A software package for analysis in experimental statistics and quantitative genetics. Acta Scientiarum. Agronomy 35: 271276.

Ferreira, R.M.A., Aroucha, E.M.M., de Souza, P.A., de Queiroz, R.F. 2009. Ponto de colheita da acerola visando à produção industrial de polpa. Revista Verde de Agroecologia e Desenvolvimento Sustentável, 4: 13-16.

Godoy, R.C.B., Matos, E.L.S., Amorim, T.D.S., Neto, M.A.D.S., Ritzinger, R., Waszczynskyj, N. 2008. Avaliação de genótipos e variedades de acerola para consumo in natura e para elaboração de doces. Boletim do Centro de Pesquisa de Processamento de Alimentos 26: 197-204.

Gonzaga Neto, L., Mattuz, B.H., Santos, C.A.F. 1999. Caracterização agronômica de clones de aceroleira (Malpighia spp) na região do submédio São Francisco. Revista Brasileira de Fruticultura 21: 110-115.

IAL. Instituto Adolfo Lutz. 2008. Métodos físicoquímicos para análise de alimentos. IAL, São Paulo, Brasil. 1020p.

IGA. Instituto de Geociências Aplicadas. 2012

Lima, P.C.C., Souza, B.S., Souza, P.S., Borges, S.D.S., Assis, M.D.O.D. 2014. Caracterização e avaliação de frutos de aceroleira. Revista Brasileira de Fruticultura 36: 550-555.

Maciel, M.I.S., Mélo, E., Lima, V., Souza, K.A., Silva, W. 2010. Caracterização físico-química de frutos de genótipos de aceroleira (Malpighia emarginata D.C.). Ciências e Tecnologia de Alimentos 30: 865-869.

Mariano-Nasser, F.A.C., Nasser, M.D.; Furlaneto, K.A.,Ramos, J.A., Vieites, R.L., 
Pagliarini, M.K. 2017. Bioactive compounds in different acerola fruit cultivares. Semina: Ciências Agrárias, 38: 2505-2514.

Matias, R. G. P., Bruckner, C. H., Carneiro, P. C. S., Silva, D. F. P., Silva, J. O. D. C. 2014. Repeatability, correlation and path analysis of physical and chemical characteristics of peach fruits. Revista Brasileira de Fruticultura, 36: 971-979.

Matias, R. G. P., Bruckner, C. H., Oliveira, J. A. A., Carneiro, P. C. S., Silva, D. F. P., \& Santos, C. E. M. 2016. Genetic diversity in peach cultivars. Comunicata Scientiae, 7: 293-301.

Moura, C.F.H., Alves, R.E., Figueiredo, R.W.D., Rodrigues de Paiva, J. 2007. Avaliações físicas e físico-químicas de frutos de clones de aceroleira (Malpighia emarginata D.C.). Revista Ciência Agronômica 38: 52-57.

Moura, N.F., Chaves, L.J., Naves, R.V. 2013. Caracterização física de frutos de pequizeiro (Caryocar brasiliense Camb.) do cerrado. Revista Árvore 37: 905-912.

Musser, R.S., Lemos, M.A., Lima, V.L.A.G., Melo, E.A., Liderman, I.E., Santos, V.F. 2004. Características físico-químicas de acerola do banco ativo de germoplasma em Pernambuco. Ciência e Tecnologia de Alimentos, 24: 556-561.

Oliveira, M.G., Oliveira, J.G., Filho, A.G., Pereira, M.G., Viana, A.P., Filho, G.A.S., Lopes, G.E.M. 2009. Diversidade genética de aceroleiras (Malphigia emarginata D.C.), utilizando marcadores moleculares RAPD e características morfoagronômicas. Revista Brasileira de Fruticultura 31: 162-170.

Pereira da Silva, D. F., Lopes de Siqueira, D., Rocha, A., Chamhum Salomão, L. C., Gonçalves Pires Matias, R., Barbosa Struiving, T. 2012. Diversidade genética entre cultivares de mangueiras, baseada em caracteres de qualidade dos frutos. Revista Ceres, 59: 225-232.

Reis, D.S., Figueiredo Neto, A., Ferraz, A.D.V., Freitas, S.T.D. 2017. Production and storage stability of acerola flour dehydrated at different temperatures. Brazilian Journal of Food Technology 20.

Reis, E. F., Pinto, J. F. N., da Assunção, H. F., da Silva, D. F. P. 2017. Diversidade genética de frutos de macaúba provenientes de 35 municípios de Goiás. Pesquisa Agropecuária Brasileira, 52: 277282.

Ritzinger, R., Ritzinger, C.H.S.P. 2011. Acerola. Informe Agropecuário32: 17-25.

Rufini, J., Galvão, E., Prezotti, L., da Silva, M. B., Parrella, R. D. C. 2011. Caracterização biométrica e físico-química dos frutos de acessos de manga'Ubá'. Revista Brasileira de Fruticultura, 33: $456-464$.

Santos, S.M., De Vasconcelos, A.M., Oliveira, V.S., Clemente, E., Costa, J.M. 2012. Evaluation of physical and physico chemical characteristics of Malpighia emarginata DC from the State of Ceará. International Journal of Biochemistry Research Review 2: 152-163.

Segtowick, E.C.S., Brunelli, L.T., Venturini Filho, W.G. 2013. Avaliação físico-química e sensorial de fermentado de acerola. Brazilian Journal of Food Technology 16: 147-154.

Silva, V.A., Machado, J.L., Resende, J.C., Oliveira, A.L., Figueiredo, U.J., Carvalho, G.R., Ferrão, M.A.G., Guimarães, R.J. 2017. Adaptability, stability, and genetic divergence of conilon coffee in Alto Suaçuí, Minas Gerais, Brazil. Crop Breeding and Applied Biotechnology 17: 25-31.

Silva, J. O. C., Gava Cremasco, J. P., Gonçalves Pires Matias, R., Pereira da Silva, D. F., Hurtado Salazar, A., Horst Bruckner, C. 2014. Divergência genética entre populações de pessegueiro baseada em características da planta e do fruto. Ciência Rural, 44: 1770-1775.

Souza, J.M.L., Negreiros, J.R.S., Álvares, V.S., Leite, F.M.N., Souza, M. L., Reis, F.S., Felisberto, F.A.V. 2008. Variabilidade físico-química da farinha de mandioca. Ciência e Tecnologia de Alimentos 28: 907-912. 